\title{
Energy conservation under extreme energy limitation: the role of cytochromes and quinones in acetogenic bacteria
}

\author{
Florian P. Rosenbaum ${ }^{1} \cdot$ Volker Müller $^{1}$
}

Received: 7 June 2021 / Accepted: 26 August 2021 / Published online: 4 September 2021

(c) The Author(s) 2021

\begin{abstract}
Acetogenic bacteria are a polyphyletic group of organisms that fix carbon dioxide under anaerobic, non-phototrophic conditions by reduction of two mol of $\mathrm{CO}_{2}$ to acetyl-CoA via the Wood-Ljungdahl pathway. This pathway also allows for lithotrophic growth with $\mathrm{H}_{2}$ as electron donor and this pathway is considered to be one of the oldest, if not the oldest metabolic pathway on Earth for $\mathrm{CO}_{2}$ reduction, since it is coupled to the synthesis of ATP. How ATP is synthesized has been an enigma for decades, but in the last decade two ferredoxin-dependent respiratory chains were discovered. Those respiratory chains comprise of a cytochrome-free, ferredoxin-dependent respiratory enzyme complex, which is either the Rnf or Ech complex. However, it was discovered already 50 years ago that some acetogens contain cytochromes and quinones, but their role had only a shadowy existence. Here, we review the literature on the characterization of cytochromes and quinones in acetogens and present a hypothesis that they may function in electron transport chains in addition to Rnf and Ech.
\end{abstract}

Keywords Anaerobes $\cdot$ Electron transport chain $\cdot$ Extremophiles $\cdot$ Thermophiles $\cdot$ Wood-Ljungdahl pathway

$\begin{array}{ll}\text { Abbreviations } \\ \text { WLP } & \text { Wood-Ljungdahl pathway } \\ \text { THF } & \text { Tetrahydrofolate } \\ \text { CODH/ACS } & \text { CO dehydrogenase/acetyl-CoA synthase } \\ \text { Coenzyme M } & \text { 2-Mercaptoethanesulfonate } \\ \text { Coenzyme B } & \text { 7-Mercaptoheptanoylthreoninephosphate } \\ \text { Ech } & \text { Energy converting hydrogenase } \\ \text { Rnf } & \text { Rhodobacter Nitrogen fixation } \\ \text { CoFeSP } & \text { Corrinoid/iron sulfur protein } \\ \text { BV } & \text { Benzylviologen } \\ \text { MF } & \text { Methanofuran } \\ \text { MQ-7 } & \text { Menaquinone-7 (2-methyl-3-heptaprenyl- } \\ & \text { 1.4-naphtoquinone) } \\ \text { MTHF } & \text { Methylene-THF } \\ \text { MTHFR } & \text { Methylene-THF reductase } \\ \text { [H] } & \text { Reducing equivalent, one electron } \\ \text { Cyt } & \text { Cytochrome } \\ \text { MP } & \text { Methanophenazine }\end{array}$

Communicated by A. Driessen.

Volker Müller

vmueller@bio.uni-frankfurt.de

1 Molecular Microbiology and Bioenergetics, Institute of Molecular Biosciences, Johann Wolfgang Goethe University, Max-von-Laue-Str. 9, 60438 Frankfurt, Germany

$\begin{array}{ll}\mathrm{F}_{420} & \text { Coenzyme } \mathrm{F}_{420} \\ \mathrm{~F}_{420} \mathrm{H}_{2} & \text { Reduced coenzyme } \mathrm{F}_{420} \\ \text { Frh } & \text { Coenzyme } \mathrm{F}_{420} \text { reducing hydrogenase } \\ \text { FDH } & \text { Formate dehydrogenase } \\ \text { UQ } & \text { Ubiquinone }\end{array}$

\section{Introduction}

Acetogenic bacteria are a polyphyletic group of strict anaerobes that are found in every possible ecosystem such as soil and water sediments or the animal intestine but also in hot, alkaline, acidic or saline environments (Drake et al. 2008). This universal distribution reflects their essential role in anaerobic food webs for they funnel carbon from various substrates such as sugars, aldehydes, carbonic acids, secondary alcohols but also $\mathrm{C} 1$ substrates and especially O-methyl, N-methyl and S-methyl groups to acetate, which is then finally converted by methanogenic archaea to methane (Daniel et al. 1988; Schink 1994; Drake et al. 2008; Schuchmann and Müller 2016). Oxidation under anoxic conditions of many of these substrates to carbon dioxide and hydrogen gas is highly endergonic, and thus does not allow microbes to grow on them unless, for example, the oxidation is coupled to the reduction of an external electron acceptor such as sulfate or carbon dioxide. 
Carbon dioxide reduction with hydrogen as electron donor is a hallmark of methanogenic archaea and acetogenic bacteria (Thauer et al. 2010; Drake et al. 2008). Both use the acetyl-CoA or Wood-Ljungdahl pathway (WLP) for the synthesis of a $\mathrm{C} 2$ unit, acetyl-CoA, from carbon dioxide (Fig. 1), which is further reductively carboxylated to pyruvate and from there funneled into the known routes for the biosynthesis of cellular monomers and polymers (Blamey and Adams 1993). The WLP is a two-branched linear pathway in which two molecules of $\mathrm{CO}_{2}$ are converted to acetyl-CoA (Ljungdahl 1986; Wood et al. 1986). In the methyl branch, the methyl group of acetyl-CoA is generated from $\mathrm{CO}_{2}$. The first step is the reduction of $\mathrm{CO}_{2}$ to a formyl group and its activation by adding it to a C1-carrying cofactor. In acetogens, this is done by two subsequent reactions, a formate dehydrogenase reduces $\mathrm{CO}_{2}$ to formate, which is then bound to the $\mathrm{C} 1$ carrier tetrahydrofolate (THF) by the enzyme formylTHF synthetase, at the expense of ATP hydrolysis (Himes and Harmony 1973; Moon et al. 2021). In methanogens, the formyl-methanofuran dehydrogenase reduces $\mathrm{CO}_{2}$ and binds the carbonyl group to the $\mathrm{C} 1$ carrier methanofuran (MF) yielding formyl-methanofuran (formyl-MF) (Leigh et al. 1985). Next, the formyl group is transferred to the other $\mathrm{C} 1$ carrier tetrahydromethanopterin (or tetrahydrosarcinapterin) and from there, the further conversion of the carbonyl group is similar in acetogens and methanogens (Kengen et al. 1988; van Beelen et al. 1984). From formyl-THF/THMP water is split off, and the resulting methenyl group is reduced via the methylene reductase to a methyl group (Clark and Ljungdahl 1982; Moore et al. 1974). In the carbonyl branch, the carbonyl group of acetyl-CoA is formed from another mol of $\mathrm{CO}_{2}$ by action of the $\mathrm{CO}$ dehydrogenase/acetyl-CoA synthase (CODH/ ACS), the key enzyme of the pathway (Pezacka and Wood 1984; Raybuck et al. 1988). In their catabolism, the two microbial groups use different routes. In methanogens, the methyl group from methyl-THMP/THSP is transferred by a methyltransferase to coenzyme M (2-mercaptoethanesulfonate) yielding methyl-CoM. The methyltransferase is a membrane-integral protein and uses the free energy of the methyltransferase reaction to expel sodium ions from the cells, thus generating an electrochemical sodium ion potential across the membrane that then drives the synthesis of ATP via an archaeal $\mathrm{A}_{1} \mathrm{~A}_{\mathrm{O}}$ ATP synthase (Deppenmeier et al. 1996; Gottschalk and Thauer 2001;

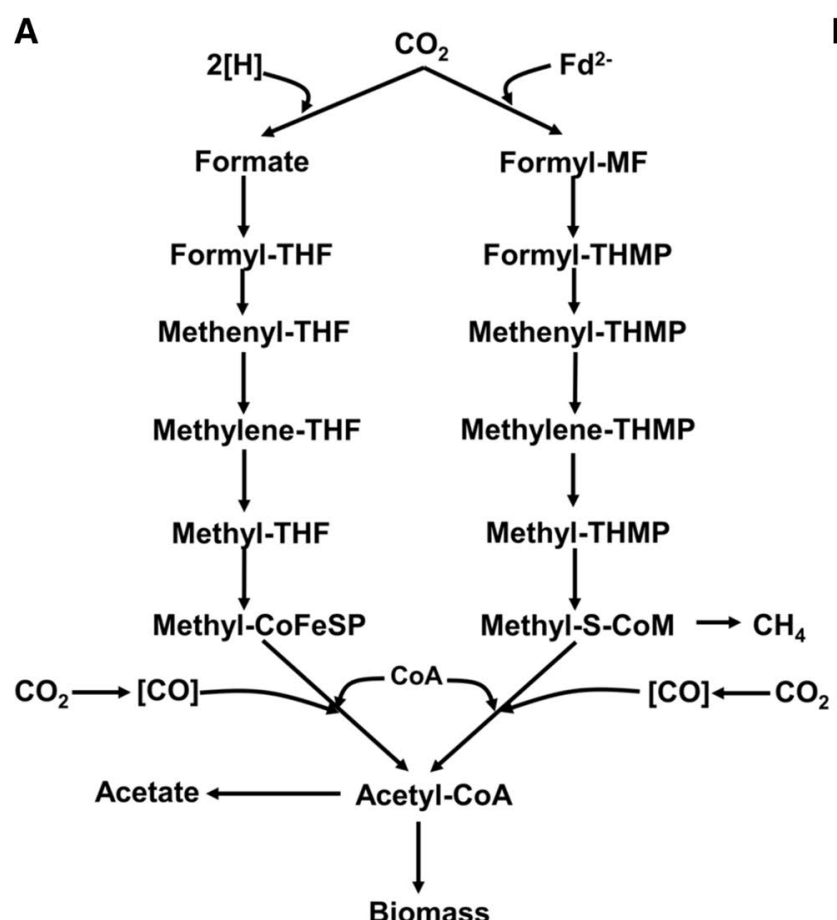

Fig. 1 The Wood-Ljungdahl pathway of acetyl-CoA formation from $\mathrm{CO}_{2}$ in acetogenic bacteria ( $\mathbf{A}$, left) and methanogenic archaea (A, right). In the anabolic route, acetyl-CoA is further converted to pyruvate and from there into the different biosynthetic routes. In the catabolic routes, acetate and methane are the end products (modified after Ljungdahl 1986; Welte and Deppenmeier 2014). B The carbon and electron flow in methanogenesis coupled to ATP synthesis by a

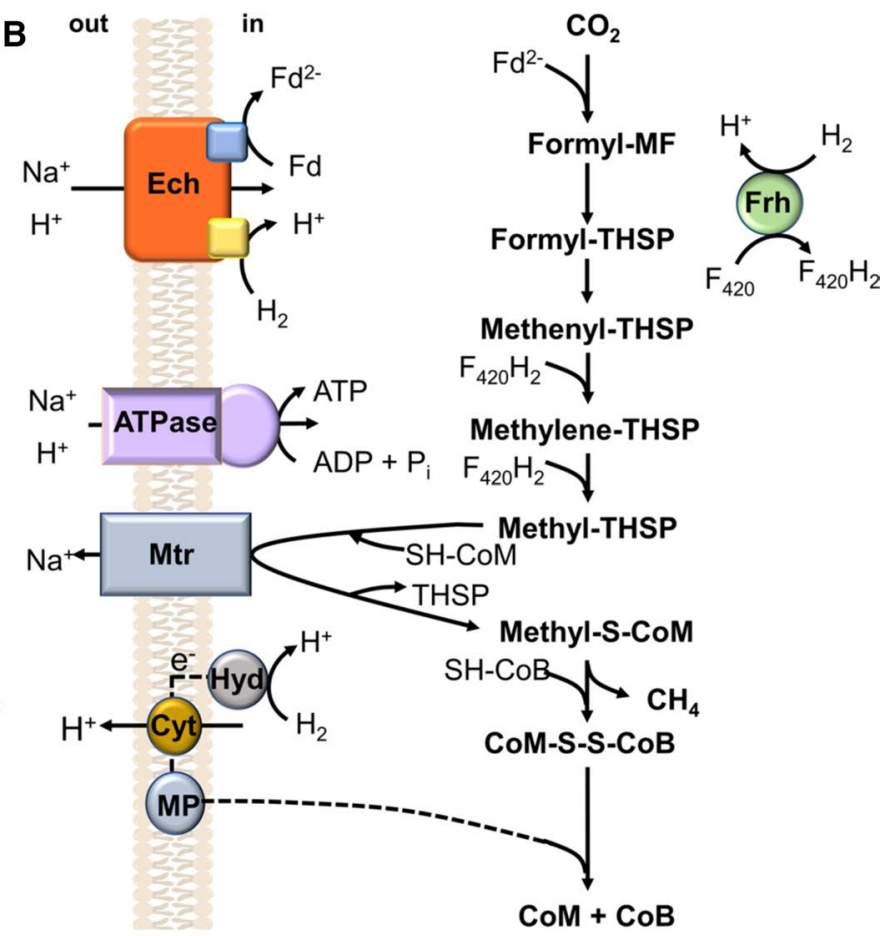

chemiosmotic mechanism in cytochrome-containing Methanosarcina species (modified after Welte and Deppenmeier 2014). The ion specificity of the ion-translocating enzymes is shown, but the stoichiometry is not indicated since it is unknown. [H], reducing equivalent, one electron; cyt, cytochrome; MP, methanophenazine; $\mathrm{F}_{420}$, coenzyme $\mathrm{F}_{420} ; \mathrm{F}_{420} \mathrm{H}_{2}$, reduced coenzyme $\mathrm{F}_{420}$; Frh, coenzyme $\mathrm{F}_{420}$ reducing hydrogenase; Mtr, methyl-THSP:CoM methyltransferase 
Müller et al. 1988a, 1999). In contrast to electron transport phosphorylation, this type of energy conservation is called methyltransfer-driven phosphorylation; both types are subsummarized under the term "chemiosmotic energy conservation" (Hess et al. 2013). In the next step, coenzyme B (7-mercaptoheptanoylthreoninephosphate) attacks the methyl group of methyl-CoM, methane is produced, and a disulfide of CoM and $\mathrm{CoB}$ is formed, the heterodisulfide (Rouvière and Wolfe 1988). The reduction of the heterodisulfide with $\mathrm{H}_{2}$ is an exergonic reaction. And now we come to the roles of cytochromes. Some methanogens such as the Methanosarcinaea have a cytochrome-containing, proton-translocating electron transport chain to reduce the heterodisulfide (Deppenmeier et al. 1996). This electron transport chain generates an electrochemical proton potential across the cytoplasmic membrane that drives the synthesis of ATP, again by an $\mathrm{A}_{1} \mathrm{~A}_{\mathrm{O}}$ ATP synthase (Deppenmeier and Müller 2008). Most of the methanogens do not have cytochromes, they employ electron bifurcation to use the exergonic reduction of the heterodisulfide to lift up the energetic level of the electron coming from hydrogen so that it reaches the energy level of ferredoxin (Thauer et al. 2008). Now, we have to turn back to the first reaction that is highly endergonic with $\mathrm{H}_{2}$ as electron donor but feasible with reduced ferredoxin. In the cytochromefree methanogens, the reduced ferredoxin generated by the electron-bifurcating heterodisulfide reaction is directly used for $\mathrm{CO}_{2}$ reduction to formyl-MF, whereas in the cytochrome-containing methanogens, the electrochemical proton potential established in the heterodisulfide reaction is used to drive reverse electron transport from hydrogen to ferredoxin catalyzed by a membrane-integral, protontranslocating, energy-converting hydrogenase (Ech) (Lie et al. 2012). So, cytochrome-containing methanogens take a little detour to reduce ferredoxin, which is required for the first reaction. This detour makes them much more flexible in that the electrochemical proton potential can, of course, also be used for other membrane-associated cellular work that has to be done by every living cell, such as osmotic work (substrate transport) and chemical work (ATP synthesis). Remarkably, the flagellum of archaea is unique, it is not using the electrochemical proton/sodium ion potential as driving force for mechanical work but ATP hydrolysis (Streif et al. 2008).

The review of the history of energy conservation in methanogens taught us the following lessons: (1) there is no substrate level phosphorylation in the WLP leading from $\mathrm{CO}_{2}$ to a methyl group, (2) one of the enzymes of the WLP, the methyltransferase, is a "respiratory" enzyme, (3) cytochromes were before seen as the hallmark of aerobes and their respiratory mechanisms. Their discovery in methanogens immediately led to the hypothesis that they must be involved in some sort of respiratory chain. (4) Most methanogens do not have cytochromes and do conserve energy in form of ATP by methyltransfer-driven phosphorylation only.

\section{Energy conservation in acetogens}

Having the history of energy conservation in methanogens in mind, we can now move on to acetogenic bacteria. During growth on $\mathrm{H}_{2}+\mathrm{CO}_{2}$, carbon dioxide is reduced to methyl-THF (Fig. 1). The methyl group is then transferred to a corrinoid/iron sulfur protein (CoFeSP) from which it is transferred to the CODH/ACS where it condenses with CoA and CO to acetyl-CoA (Diekert and Ritter 1982; Drake et al. 1980; Hu et al. 1982). Phosphotransacetylase catalyzes the formation of acetyl phosphate and acetate kinase the formation of acetate and ATP. The overall free energy change of the reaction (Eq. 1):

$2 \mathrm{CO}_{2}+4 \mathrm{H}_{2} \rightarrow \mathrm{CH}_{3} \mathrm{COO}^{-}+\mathrm{H}^{+}+2 \mathrm{H}_{2} \mathrm{O} \Delta \mathrm{G}_{0}^{\prime}=-95 \mathrm{~kJ} / \mathrm{mol}$,

is only enough to make only around 1.5 ATP under standard conditions (Schuchmann and Müller 2014). However, if we take into calculation the actual hydrogen partial pressures that have been determined in the environments, which is less than $1 \mu \mathrm{M}$, we end up with approximately $0.3 \mathrm{~mol}$ ATP/ mol acetate (Conrad et al. 1986). This is life at the thermodynamic edge and the question was for a long time how this pathway is coupled to the net synthesis of ATP (Müller 2003). One ATP is gained in the acetate kinase reaction, but one ATP has to be invested in the activation of formate; therefore, the ATP gain by substrate level phosphorylation is zero and an additional mechanism of energy conservation must exist. Having described that the discovery of cytochromes in a species is ultimately seen as evidence for an energy-conserving respiratory chain, it is not surprising that the discovery of cytochromes in one acetogen excited the entire field. The discovery of $b$-type cytochromes in Moorella thermoacetica (formerly Clostridium thermoaceticum) in 1975 by Gottwald et al. was immediately taken as indication for cytochrome-dependent electron transport chain as part of a chemiosmotic mechanism of ATP synthesis and extrapolated to the entire group of acetogens (Gottwald et al. 1975; Hugenholtz and Ljungdahl 1990). Later, reduction of cytochromes as well as the concomitant generation of a membrane potential in vesicles of Moorella thermoautotrophica (formerly Clostridium thermoautotrophicum) was detected but the physiological processes involved remained enigmatic (Hugenholtz et al. 1987).

The beauty of microbiology is mirrored in the beauty of microbial diversity. Today, 23 genera of acetogens are described and acetogenic bacteria are spread over the entire phylogenetic tree (Drake et al. 2008; Müller and Frerichs 
Table 1 Presence of Rnf, Ech, Ion dependence of the ATP synthase, presence of cytochromes, quinones, HdrABCMvhD and Fix complexes in acetogens

\begin{tabular}{|c|c|c|c|c|c|c|c|c|}
\hline Organism & Rnf & Ech & ATP synthase & $\mathrm{Cyt}^{1}$ & Quinon $^{2}$ & $\mathrm{Hdr}$ & Fix & Remarks \\
\hline Acetobacterium woodii DSM 1030 & + & - & $\mathrm{Na}^{+}$ & - & - & - & - & \\
\hline Acetobacterium bakii DSM 8239 & + & $*$ & $\mathrm{Na}^{+}$ & - & - & - & - & Ech-like complex* \\
\hline Acetobacterium dehalogenans DSM 11527 & + & - & $\mathrm{Na}^{+}$ & - & - & - & - & \\
\hline Acetobacterium wieringae DSM 1911 & + & - & $\mathrm{Na}^{+}$ & - & - & - & - & \\
\hline Acetoanaerobium noterae ATCC 35199 & + & - & $\mathrm{Na}^{+}$ & - & - & - & - & \\
\hline Acetoanaerobium sticklandii DSM 519 & + & - & $\mathrm{Na}^{+}$ & - & - & - & - & \\
\hline Acetohalobium arabaticum DSM 5501 & + & * & $\mathrm{Na}^{+}$ & - & $++^{3}$ & - & - & Ech-like complex* \\
\hline Acetonema longum DSM 6540 & - & + & $\mathrm{H}^{+}$ & - & $++^{3}$ & - & - & \\
\hline Acetitomaculum ruminis DSM 5522 & + & - & $\mathrm{Na}^{+}$ & - & - & - & - & \\
\hline Alkalibaculum bacchi DSM 22112 & + & - & $\mathrm{Na}^{+}$ & - & - & - & - & \\
\hline Blautia coccoides DSM 935 & + & - & $\mathrm{H}^{+}$ & - & - & + & - & \\
\hline Blautia hydrogenotrophica DSM 10507 & + & - & $\mathrm{H}^{+}$ & - & - & - & - & \\
\hline Blautia luti & + & - & $\mathrm{H}^{+}$ & - & - & + & - & \\
\hline Blautia producta DSM 2950 & + & - & $\mathrm{H}^{+}$ & - & - & + & - & \\
\hline Blautia schinkii 10518 & + & - & $\mathrm{H}^{+}$ & - & - & - & - & \\
\hline Blautia wexlerae 19850 & + & - & $\mathrm{H}^{+}$ & - & - & + & - & \\
\hline Clostridium aceticum DSM 1496 & + & - & $\mathrm{Na}^{+}$ & $\mathrm{c}$ & - & - & - & Cyt. and nitrite reductase in one cluster \\
\hline Clostridium acetobutylicum DSM 1732 & + & - & $\mathrm{H}+$ & - & - & - & - & \\
\hline Clostridium autoethanogenum DSM 10061 & + & - & $\mathrm{H}^{+}$ & - & - & - & \# & Fix-like complex ${ }^{\#}$ \\
\hline Clostridium carboxidivorans DSM 15243 & + & $*$ & $\mathrm{H}^{+}$ & - & - & - & - & Ech-like complex* \\
\hline Clostridium coskatii ATCC PTA-10522 & + & - & $\mathrm{H}^{+}$ & - & - & - & \# & Fix-like complex ${ }^{\#}$ \\
\hline Clostridium difficile 630 DSM 27543 & + & - & $\mathrm{Na}^{+}$ & - & - & - & - & \\
\hline Clostridium drakei DSM 12750 & + & - & $\mathrm{H}^{+}$ & - & - & - & - & \\
\hline Clostridium formicaceticum DSM 92 & + & - & $\mathrm{Na}^{+}$ & $\mathrm{c}$ & - & - & - & Cyt. and nitrite reductase in one cluster \\
\hline Clostridium ljungdahlii DSM 13528 & + & - & $\mathrm{H}^{+}$ & - & - & - & $\#$ & Fix-like complex ${ }^{\#}$ \\
\hline Clostridium magnum DSM 2767 & + & - & $\mathrm{H}^{+}$ & - & - & - & \# & Fix-like complex ${ }^{\#}$ \\
\hline Organism & Rnf & Ech & ATP synthase & Cyt & Quinon & $\mathrm{Hdr}$ & Fix & Additional Information \\
\hline Clostridium methoxybenzovorans DSM 12182 & + & - & $\mathrm{H}^{+}$ & - & - & - & - & \\
\hline Clostridium ragsdalei DSM 15248 & + & - & $\mathrm{H}^{+}$ & - & - & - & - & \\
\hline Clostridium scatologenes DSM 757 & + & $*$ & $\mathrm{H}^{+}$ & - & - & - & - & Ech-like complex* \\
\hline Clostridium sp. AWRP & + & - & $\mathrm{H}^{+}$ & - & - & - & - & \\
\hline Clostridium sp. P21 & + & - & $\mathrm{H}^{+}$ & - & - & - & - & \\
\hline Clostridium ultunense DSM 10521 & + & - & $\mathrm{Na}^{+}$ & - & - & - & - & \\
\hline Eubacterium aggregans SR 12 & + & - & $\mathrm{Na}^{+}$ & - & - & + & - & \\
\hline Eubacterium limosum KIST612 & + & - & $\mathrm{Na}^{+}$ & - & - & - & - & \\
\hline Holophaga foetida 6591 & - & * & $\mathrm{H}^{+}$ & - & - & - & - & Ech-like complex* \\
\hline Moorella glycerini NMP & - & + & $\mathrm{H}^{+}$ & $\mathrm{b}$ & MQ & + & + & \\
\hline Moorella humiferrea DSM 23265 & - & $*$ & $\mathrm{H}^{+}$ & $\mathrm{b}$ & MQ & + & + & Ech-like complex* \\
\hline Moorella mulderi DSM 14980 & - & + & $\mathrm{H}^{+}$ & $\mathrm{b}$ & MQ & + & + & \\
\hline Moorella thermoacetica DSM 521 & - & + & $\mathrm{H}^{+}$ & $\mathrm{b}$ & MQ & + & + & \\
\hline Moorella thermoautotrophica & - & + & $\mathrm{H}^{+}$ & $\mathrm{b}$ & MQ & + & + & \\
\hline Sporomusa acidovorans DSM 3132 & + & - & $\mathrm{H}^{+}$ & $\mathrm{b} / \mathrm{c}$ & UQ & + & + & \\
\hline Sporomusa aerivorans DSM 13326 & + & - & $\mathrm{H}^{+}$ & $\mathrm{b} / \mathrm{c}$ & UQ & + & + & \\
\hline Sporomusa malonica DSM 5090 & + & - & $\mathrm{H}^{+}$ & $\mathrm{b} / \mathrm{c}$ & UQ & + & + & \\
\hline Sporomusa ovata DSM 2662 & + & $*$ & $\mathrm{H}^{+}$ & $\mathrm{b} / \mathrm{c}$ & UQ & + & + & $\begin{array}{l}\text { Ech-like complex fix-complex split } \\
\text { into two clusters* }\end{array}$ \\
\hline Sporomusa sphaeroides Strain E & + & - & $\mathrm{H}^{+}$ & $\mathrm{b} / \mathrm{c}$ & UQ & + & + & \\
\hline Sporomusa silvacetica DSM 10669 & + & - & $\mathrm{H}^{+}$ & $\mathrm{b} / \mathrm{c}$ & UQ & + & + & \\
\hline
\end{tabular}


Table 1 (continued)

\begin{tabular}{llllllllll}
\hline Organism & Rnf & Ech & ATP synthase & Cyt & Quinon & Hdr & Fix & Additional Information \\
\hline Sporomusa termitida & + & - & $\mathrm{H}^{+}$ & & $\mathrm{b} / \mathrm{c}$ & $\mathrm{UQ}$ & + & + & \\
Thermoanaerobacter kivui DSM 2030 & - & + & $\mathrm{H}^{+}$ & & - & - & - & - & \\
Thermacetogenium phaeum DSM 12270 & - & + & $\mathrm{H}^{+}$ & & - & $\mathrm{MQ}$ & + & + \\
Tindallia californiensis APO & - & + & $\mathrm{Na}^{+}$ & - & - & + & - \\
Treponema azotonutricium DSM 13862 & + & - & $\mathrm{H}^{+}$ & - & - & - & - \\
\hline
\end{tabular}

1 "c" or "b" denotes the type of cytochrome

${ }^{2} M Q$ menaquinone, $U Q$ ubiquinone

${ }^{3}$ not further characterized

",Ech-like complex" denotes for the presence of genes that encode proteins with similarity to some Ech subunits, but not a full complex

\#"'Fix-like complex" denotes for a complex present in quinone-free organisms; therefore, its function cannot be as described in quinone-containing organisms

2013). Some tribes have only acetogens, other have other metabolic types as well. Therefore, as with the methanogens, only a few acetogens do have membrane-bound electron carriers such as cytochromes or quinones (Table 1), the majority does not have cytochromes or quinones! Indeed, the first conclusive evidence how acetogens conserve energy comes from a study with Acetobacterium woodii, a species that does neither have cytochromes nor quinones. First, although it had been postulated based on the finding of a "respiratory" methyltransferase in methanogens that a methyltransferase of the WLP in acetogens is the chemiosmotic coupling site, this could be ruled out with certainty for $A$. woodii and for any other sequenced acetogen (Müller 2003; Schuchmann and Müller 2014). Second, the energy-conserving site is not in the WLP per se, but in the electron pathway leading to the reduction of electron carriers required for the WLP. Membranes of $A$. woodii have a novel respiratory electron transport complex that catalyzes ferredoxin:NAD oxidoreductase activity, the Rnf complex, where Rnf stands for "Rhodobacter nitrogen fixation" (Fig. 2) (Imkamp et al. 2007; Biegel and Müller 2010; Biegel et al. 2011; Hess et al. 2013, 2016). The enzyme is reversibly coupled to the electrochemical ion potential across the membrane and pumps out $\mathrm{Na}^{+}$when electron flow is exergonic, that is from reduced ferredoxin to NAD, whereas the endergonic backward reaction is energetically driven by $\mathrm{Na}^{+}$influx along the electrical field (Hess et al. 2013). Again, the beauty of metabolic diversity comes into our way, Rnf complexes from some acetogens use $\mathrm{Na}^{+}$, others use $\mathrm{H}^{+}$instead (Table 1). This is not surprising considering that the change of only two amino acids out

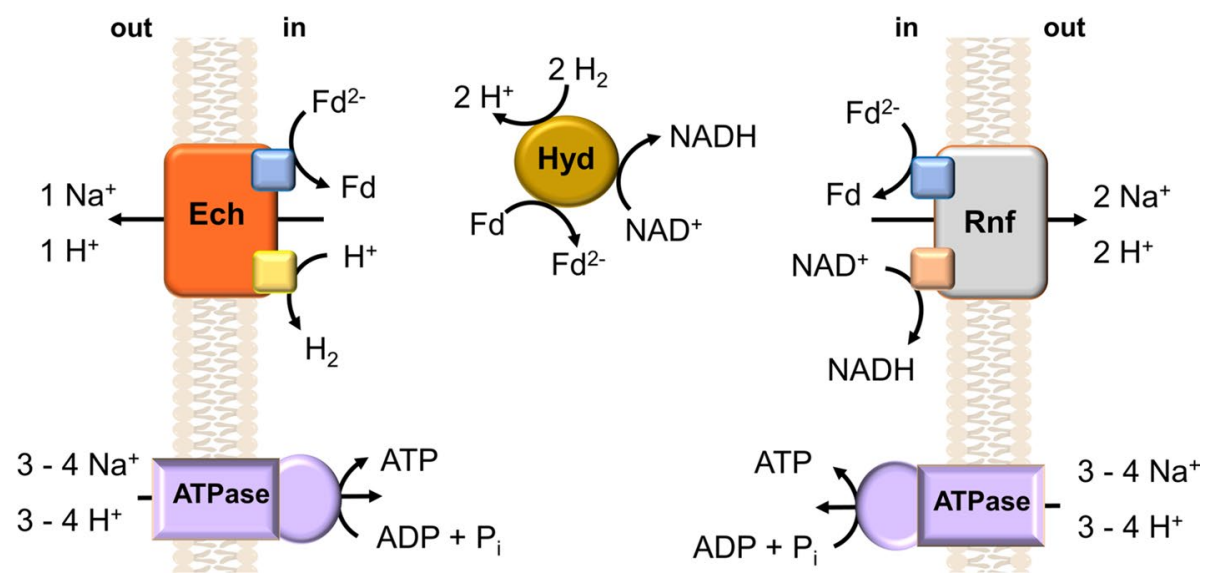

Fig. 2 Energy conservation by a chemiosmotic mechanism in acetogenic bacteria. Depicted is an Ech- (left) and a Rnf-containing respiratory chain (right). An electron-bifurcating, ferredoxin and NADreducing hydrogenase provides reduced ferredoxin as fuel for both electron transport chains (Schuchmann and Müller 2012). In principle Rnf, Ech and ATP synthase can use $\mathrm{Na}^{+}$or $\mathrm{H}^{+}$as coupling ion. This has been experimentally verified for $\mathrm{Rnf}\left(\mathrm{Na}^{+}\right.$in $A$. woodii by
Hess et al. 2013, $\mathrm{H}^{+}$in C. ljungdahlii by Tremblay et al. 2012), Ech $\left(\mathrm{Na}^{+}\right.$and $\mathrm{H}^{+}$in T. kivui by Schoelmerich and Müller 2019) and ATP synthase $\left(\mathrm{Na}^{+}\right.$in $A$. woodii by Reidlinger and Müller $1994 ; \mathrm{H}^{+}$in $M$. thermoacetica by Das and Ljungdahl 1997). See Table 1. for ion specificities of ATP synthases in acetogens. Ech is indicated to pump one ion per two electrons, Rnf two ions per two electrons. The stoichiometry is based on thermodynamic considerations 
of roughly 7000 changes the substrate specificity from $\mathrm{H}^{+}$ to $\mathrm{Na}^{+}$in ATP synthases (Müller and Grüber 2003; Grüber et al. 2014). As a side note it is important to realize that acetogens can thrive on energy poor substrates that can only be used to reduce NAD; then, the Rnf complex is used to provide the cell with reduced ferredoxin for biosynthetic reactions (Bertsch et al. 2016; Westphal et al. 2018).

Again, we are hit by the beauty of metabolic diversity. Inspection of genome sequences revealed that the Rnf complex is not universally found in acetogens and nearly 10 years after the discovery of the Rnf complex, a second respiratory enzyme was found in acetogens, the Ech complex (Fig. 2) (Schoelmerich and Müller 2019). The Ech also uses reduced ferredoxin as electron donor for an enzyme-bound electron transport chain, but protons, not NAD, as acceptor, leading to the production of hydrogen gas as end product of this respiration (Schoelmerich and Müller 2019, 2020; Welte et al. 2010). As of today, acetogens have either Rnf or Ech, not both, in one cell (Table 1), although some nonacetogenic rumen bacteria have been reported to have $\mathrm{Rnf}$ and Ech complexes operative in one cell (Hackmann and Firkins 2015; Schoelmerich et al. 2020). Anyway, the important message is that every acetogen analyzed or sequenced so far possesses either Rnf or Ech (Fig. 2). Therefore, it is justified to energetically classify the acetogens in the groups of Rnf and Ech acetogens (Schuchmann and Müller 2014). Since Rnf and Ech are electron transport-driven ion pumps operating by conformational changes, both complexes can, in principle, translocate $\mathrm{Na}^{+}$or $\mathrm{H}^{+}$, based on the nature of the ion-binding pocket. The same change in ion specificity is found in ATP synthases, the flagellar motor, ion-coupled secondary transporter or the transhydrogenase (Homma et al. 1985; Kawagishi et al. 1996; Müller and Grüber 2003; Khafizov et al. 2012; Luoto et al. 2013).

\section{Cytochromes and quinones in acetogens}

After having worked out that every acetogen known to date has a ferredoxin-dependent respiratory enzyme that does not involve cytochromes the question of course is: what is the role of the cytochromes? A solution to this question may come from the analysis of the distribution of cytochromes, their different nature and the physiological activities of the organisms cytochromes have been found in. The picture is complicated by the fact that many acetogens can reduce a number of alternative substrates such as pyruvate, fumarate, aromatic acrylates, inorganic sulfur compounds and nitrate or nitrite in addition to $\mathrm{CO}_{2}$ (Dorn et al. 1978; Bache and Pfennig 1981; Tschech and Pfennig 1984; Beaty and Ljungdahl 1990; Matthies et al. 1993; Seifritz et al. 1993, 2003; Fröstl et al. 1996; Misoph et al. 1996; Misoph and Drake 1996; Arendsen et al. 1999; Hattori et al. 2000). $c$-type cytochromes such as cytochrome $c_{3}$ $\left(E_{0}^{\prime}=-200 \mathrm{mV}\right)$ are typical constituents of respiratory chains leading to the reduction of nitrate (Thauer et al. 1977). Some Sporomusa and Clostridia species can reduce nitrate, which may involve cytochrome $\mathrm{c}$ as electron donor. Furthermore, $C$. ljungdahlii can co-utilize $\mathrm{CO}_{2}$ and nitrate with a reductase which is not associated to cytochrome c. This co-utilization of $\mathrm{CO}_{2}$ and nitrate enhanced biomass formation from $\mathrm{H}_{2}+\mathrm{CO}_{2}$ (Emerson et al. 2019). Mechanistically, it is not known whether nitrate reduction is coupled to energy conservation for example via a nitrate-dependent ion-motive respiratory chain or whether the presence of nitrate redirects electrons to the Rnf- and Ech complexes thus providing more fuel for chemiosmotic ATP synthesis (Seifritz et al. 1993, 2002). A proteome study revealed that the genes for the biosynthesis of cytochrome $c$ were upregulated together with the genes encoding nitrate and nitrite reductase specifically in the presence of nitrate (Visser et al. 2016). Furthermore, a similar circumstance can be suggested for the acetogens Clostridium aceticum and Clostridium formicoaceticum since genes involved for the cytochrome $c$ synthesis are clustered with a nitrate reductase (Table 1). Although this is only circumstantial evidence it is very plausible that cytochrome $c$ is involved in electron transport towards nitrate and maybe other alternative electron acceptors as well. Intercellular electron transfer may also be possible, but this has not been addressed in acetogens.

$b$-type cytochromes such as cytochrome $b_{559}$ or $b_{554}$ $\left(\mathrm{E}_{0}{ }^{\prime}=-200\right.$ and $\left.-48 \mathrm{mV}\right)$ are known as membrane anchors of dehydrogenases and hydrogenases that transfer electrons via the membrane-bound electron carriers (Das et al. 1989; Dobrindt and Blaut 1996; Kröger et al. 2002). In M. thermoacetica, nitrate represses acetate formation as terminal electron acceptor through the WLP and in one study, the activity of the enzymes of the WLP was not affected, whereas in another it was found that the synthesis of the WLP enzymes was downregulated by nitrate, including the synthesis of the $b$-type cytochrome (Arendsen et al. 1999; Fröstl et al. 1996). This would argue for the $b$-type cytochrome being involved in electron transfer to the WLP enzymes.

\section{Hypothesis: membrane-bound, cytochrome- and/or quinone-dependent electron transport chains in acetogens}

If we consider the argument again that $b$-type cytochromes are membrane anchors for dehydrogenases and hydrogenases what could be the donors and acceptors of such electron transport chain? Of course, they could be very different given the beauty of diversity in electron donors and acceptors used by acetogens. But if we, for now, focus 
on the WLP, reduction of methylene-THF to methyl-THF $\left(E_{0}{ }^{\prime}=-200 \mathrm{mV}\right)$ has a very positive redox potential and reduction of methylene-THF with NADH as reductant is the most exergonic reaction of the pathway (Wohlfarth and Diekert 1991). Whether or not this reaction is energy conserving has not been proven, despite the fact that this was already postulated nearly 45 years ago (Thauer et al. 1977). The most conclusive evidence that the $b$-type cytochromes are involved in electron transfer to the WLP was presented by Kamlage and Blaut, already in 1993 (Kamlage and Blaut 1993). By showing that a cytochrome $b$-deficient mutant was no longer able to oxidize methyl groups to $\mathrm{CO}_{2}$ or reduce $\mathrm{CO}_{2}$ to the level of a methyl group, they laid the foundation for the hypothesis that $b$-type cytochromes are involved as electron carrier in electron transfer to methylene-THF (MTHF) (Kamlage and Blaut 1993). Later on, the group of Michael Blaut isolated a membrane-bound hydrogenase that had a cytochrome $b$-containing subunit (Dobrindt and Blaut 1996). With that discovery it was plausible to assume a periplasmic hydrogenase that oxidizes hydrogen at the outside, thus generating scalar protons. The electron is then passed via cytochrome $b$ to the acceptor, methylene-THF reductase (MTHFR) (Fig. 3). ATP is synthesized driven by the electrochemical proton potential generated by the scalar protons. It should be mentioned that such hydrogenase-dependent,

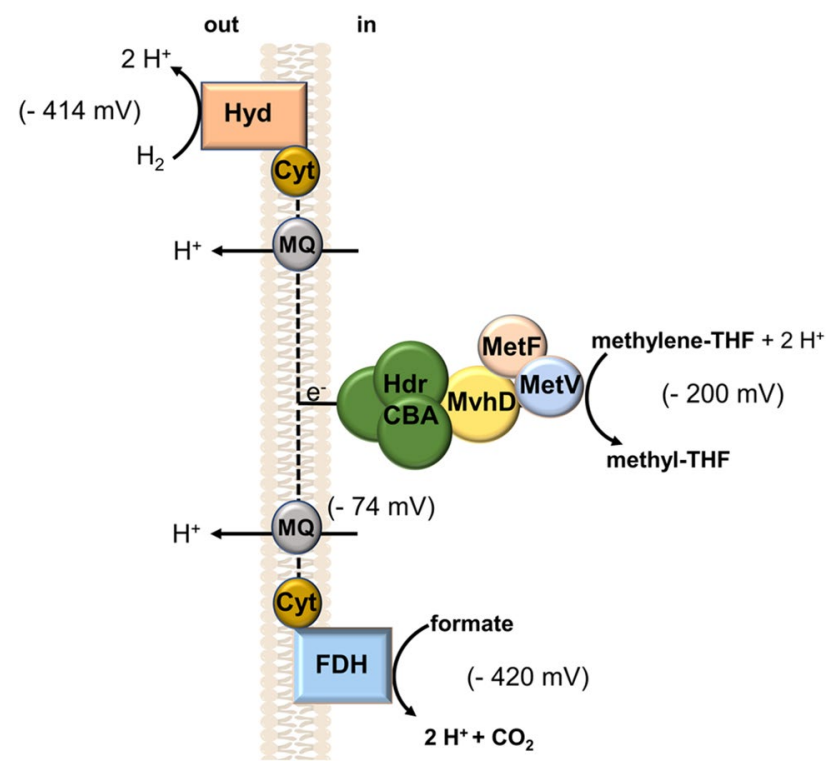

Fig. 3 Hypothetical cytochrome- and menaquinone-containing energy-conserving electron transport chains. In this example, the MetFVHdrABCMvhD complex is not indicated to bifurcate electrons to two acceptors. Please note that proton translocation is related to oxidation/reduction of MQ and requires a membrane-integrated protein to catalyze this reaction. Hyd, hydrogenase; FDH, formate dehydrogenase; Cyt, cytochrome; MQ, menaquinone; MetFV, methyleneTHF reductase; HdrABCmvhD, a hypothetical linker of the MetFV methylene-THF reductase to a component in the cytoplasmic membrane energy-conserving electron transport chains are widespread in the anaerobic world (Kröger et al. 2002).

An involvement of cytochromes in the MTHFR reaction was also very recently speculated by Keller et al. (2019) for the thermophile Thermacetogenium phaeum (Keller et al. 2019). This acetogen can grow on formate that is converted to acetate via the WLP. From a detailed proteomic and enzymatic study, it was suggested that two mol of formate are oxidized by a soluble formate dehydrogenase to $\mathrm{CO}_{2}$ to provide NADH and ferredoxin for the methylene-THF dehydrogenase and CODH/ACS, respectively. The third mole of formate is suggested to be oxidized by a membrane-bound formate dehydrogenase/quinone oxidoreductase to reduce menaquinone-7 $\left(\mathrm{E}_{0}{ }^{\prime}=-74 \mathrm{mV}\right)$. The final acceptor is supposed to be the MTHFR (Fig. 3). A similar system was proposed on theoretical grounds for M. thermoacetica (Mock et al. 2014). Since there is no indication that the formate dehydrogenase and the MTHFR are periplasmic, energy conservation must occur by vectorial proton transport coupled to this reaction.

The WLP is reversible and is used by T. phaeum for the oxidation of acetate to formate $/ \mathrm{H}_{2}+\mathrm{CO}_{2}$ or by $S$. ovata and S. sphaeroides for the oxidation of methanol to $\mathrm{CO}_{2}$ and $\mathrm{H}_{2}$. Therefore, it is mandatory that the before mentioned electron transport chains are reversible. MTHF oxidation with NAD reduction is endergonic and the energy to overcome the energy barrier is provided in this example by reverse electron transport. Mutant studies with $S$. sphaeroides are in fact in line with this hypothesis as well as proteome studies in $T$. phaeum (Kamlage and Blaut 1993; Keller et al. 2019). In the latter, acetate is oxidized to formate which is then transferred to a syntrophic partner, to make the overall acetate oxidation energetically feasible. However, proteome analyses revealed evidence for a different formate dehydrogenase present in the periplasm thus producing a scalar proton gradient.

Let us now turn to the MTHFR. Since this is the only exergonic reaction of the WLP and since methanogens had been shown by one of us already in 1988 to couple reduction of formaldehyde (methylene-THSP) to the methyl level with translocation of sodium ions across the membrane (Müller et al. 1988b), a rush started to identify the MTHFR as membrane-bound, electron transfer-driven ion pump. However, all attempts using A. woodii, Acetobacterium dehalogenans, $S$. sphaeroides and $M$. thermoacetica failed in a sense that most of the enzyme was always found in the soluble fraction, strongly arguing against a role in membrane-bound electron transport. Therefore, the enzyme fell into oblivion for decades. With the unraveling of genome sequences evidence for membrane localization was also not obtained and the view of a soluble MTHFR was solidified. Therefore, it was no surprise that the enzyme was purified from the cytoplasm of $A$. woodii (Bertsch et al. 2015). It contained the subunits MetF and MetV and an additional subunit, RnfC2, 
that catalyzes NADH oxidation. And indeed, the soluble enzyme catalyzed MTHF reduction with NADH as reductant (Bertsch et al. 2015). But again, the beauty of metabolic diversity gets into our way: many acetogenic species have $m e t F V$ but not the $r n f C 2$ gene (Öppinger et al. 2021). Mock et al. described in $M$. thermoacetica a gene cluster that contains $m e t F V$ next to $h d r C B A$ and $m v h D$; these genes were part of one transcriptional message arguing for the proteins being functional in the same context (Mock et al. 2014). In the thermophile Methanobacterium thermoautotrophicus, the $h d r$ genes were found to build an electron-bifurcating enzyme complex (Fig. 4A). $\mathrm{H}_{2}$ is oxidized by MvhA and the electrons are passed via MvhG and D to HdrA. The flavin in $\mathrm{HdrA}$ is the branching point, leading to the heterodisulfideand ferredoxin-reduction site (Kaster et al. 2011; Wagner et al. 2017). Therefore, it is tempting to speculate that the HdrABCMvhD subunits confers electron bifurcation to the MTHFR. Although one has to consider important functional differences. HdrA of $M$. thermoacetica but not $M$. thermoautotrophica has a diaphorase activity oxidizing NADH and the HdrABCMvhDMetFV complex purified from $M$. thermoacetica does not reduce ferredoxin (Mock et al. 2014). A possible electron bifurcation by the complex could not be demonstrated, although several obvious electron carriers were tested. Therefore, the authors concluded that the complex "is somehow docked" to the membrane and the membrane respiratory electron acceptor has a redox potential comparable to ferredoxin, allowing for proton reduction to $\mathrm{H}_{2}$, as catalyzed by Ech (Fig. 4B).

Ech complexes often interact with carbon monoxide and, consistent with this hypothesis, $\mathrm{CO}$ - (reduced ferredoxin-) dependent electron transport at membrane vesicles of M. thermoautotrophica and the concomitant built up of a membrane potential has been observed (Hugenholtz and Ljungdahl 1989). A similar genetic organization of metFVhdrCBAmvhD was found in T. phaeum and also there the proteins were discussed to electrically connect the MTHFR to the membrane. In sum, it is conceivable that in some species (that have a MetFVHdrABCMvhD complex) the MTHFR is indeed electrically connected to the membrane. During carbon flow from $\mathrm{CO}_{2}$ /formate, it serves as electron acceptor for a membrane-bound, energy-conserving respiratory chain that involves quinones and cytochromes, but the latter are not mandatory. If a $\mathrm{NiFe}$ hydrogenase is involved as electron input/output module, cytochrome $b$ maybe involved. If a formate dehydrogenase is involved cytochromes are most likely not involved.

So far, we have discussed the role of cytochromes and quinones in electron transport processes in which the electron source such as formate or hydrogen is directly oxidized at the membrane. What about NADH as electron donor for quinone reduction? We already know about the beauty of metabolic diversity in acetogens and would wonder if there is no solution to involve NADH-dependent quinone reduction. Indeed, there is a solution to couple NADH oxidation and subsequent (mena)quinone reduction. Ledbetter and colleagues characterized a bifurcating enzyme complex called FixABCX, which has been proposed to oxidize NADH and reduce ferredoxin subsequently with quinone via bifurcation (Ledbetter et al. 2017). In this context, the role of Fix ABCX in acetogens has not yet been addressed. FixAB is equivalent to EtfAB, FixC is the quinone reductase. Interestingly, genes encoding Fix ABCX are present in only some acetogens such as Moorella and Sporomusa species (Table 1). NADH oxidation would allow for ferredoxin reduction, and the resulting high potential menaquinone could be the electron donor for a second bifurcating reaction, that uses NADH as co-reductant to drive the endergonic reduction of methylene-THF with the high potential menaquinone
A

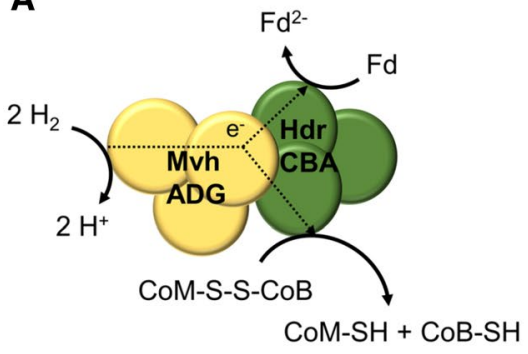

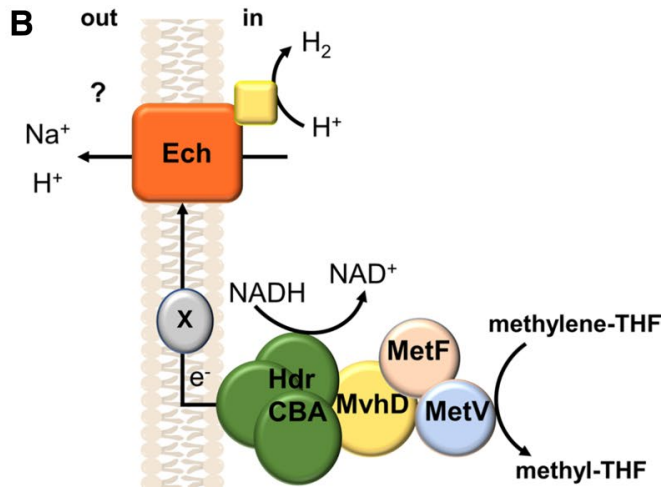

known cytochromes and menaquinone would be too high $(-200$ and $-74 \mathrm{mV}$ ) therefore, electron transfer may involve an unknown membrane-integral carrier (X). In this example, the MetFVHdrABCMvhD complex is assumed to bifurcate electrons from NADH to methyleneTHF and finally to protons 


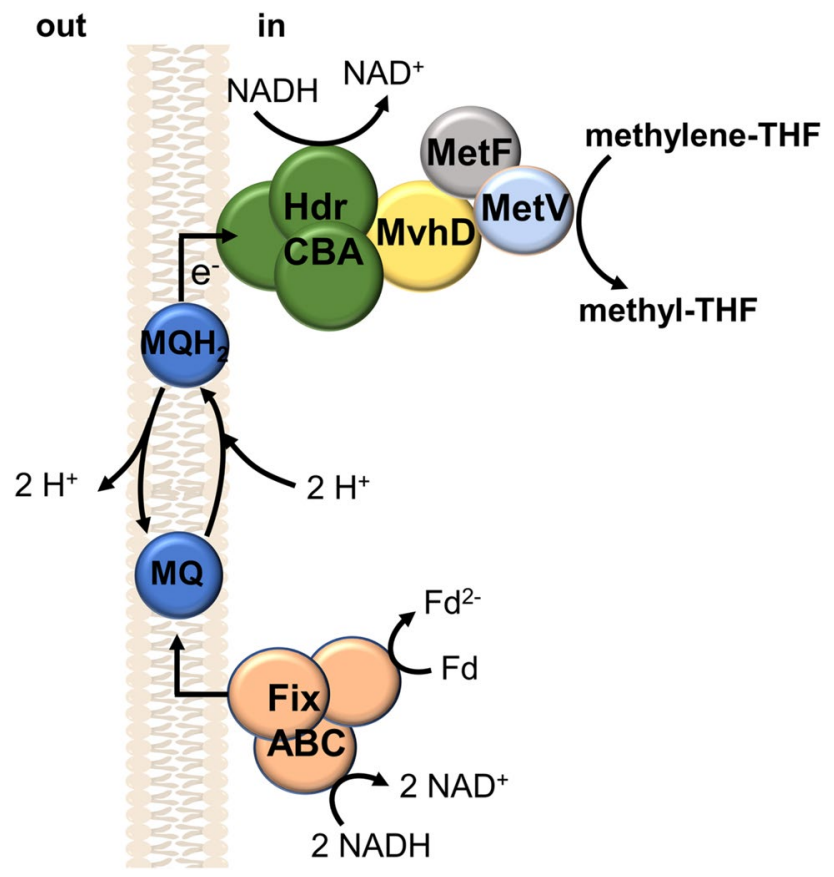

Fig. 5 Hypothetical coupling of NADH oxidation to the reduction of methylene-THF by two consecutive electron-bifurcating reactions, catalyzed by FixABCX and the MetFVHdrABCMvhD complex. A quinone cycle may be involved in generating an electrochemical field across the membrane for ATP synthesis. Please note that proton translocation is related to oxidation/reduction of MQ and requires a membrane-integrated protein to catalyze this reaction

as electron donor (Fig. 5). In this context it is interesting to note that the FixABCX complex is widespread in bacteria and was recently shown to allow sulfate reducers to grow on ethanol. Oxidation of ethanol to acetaldehyde $\left(\mathrm{E}_{0}{ }^{\prime}=-190 \mathrm{mV}\right)$ with reduction of $\mathrm{NAD}^{+}$is endergonic and overcome by coupling to NADH oxidation by the electron-bifurcating FixABCDHdrABC complex (Ramos et al. 2015). Similarly, oxidation of lactate to pyruvate $\left(\mathrm{E}_{0}{ }^{\prime}=-190 \mathrm{mV}\right)$ also does not allow for $\mathrm{NAD}^{+}$reduction and acetogens have evolved different ways to overcome the energetic barrier. One is by electron bifurcation with concomitant oxidation of reduced ferredoxin (Weghoff et al. 2015), another recently suggests coupling to a FixABCX/ membrane-bound electron transfer as predicted in Fig. 5 (Rosenbaum et al. 2021).

Since carbon dioxide does not serve exclusively as final electron acceptor in acetogens the question arises whether the reduction of alternative final electron acceptors may require quinones? In theory the answer is yes, the genome sequencing of $M$. thermoacetica reveals the presence of a DMSO reductase (Pierce et al. 2008). Since there is no experimental evidence for DMSO reduction by acetogens, it can be only speculated whether and if so, how DMSO is reduced in this ecophysiologically important group of bacteria.

\section{Conclusions}

Cytochromes and quinones were the first respiratory components found in acetogens. Unfortunately, they sank into a long sleeping beauty slumber, which is not yet really over. Cytochrome-dependent respiratory chains in acetogens are suggested for nearly 50 years but it is far from being settled whether they are present or not. However, if they are present, they are only in addition to the Rnf or Ech complex. Here, the situation is comparable to methanogens. Every methanogen that grows on $\mathrm{H}_{2}+\mathrm{CO}_{2}$ and that has been studied or sequenced so far has the sodium ion pump methyl-THMP/THSP:CoM methyltransferase, but some have cytochrome-containing respiratory chains in addition. Every acetogen possesses an energy coupling site, either Rnf or Ech but just a few acetogens have in addition cytochromes and quinones, such as Sporomusa, M. thermoacetica or Clostridium aceticum (Gottwald et al. 1975; Poehlein et al. 2015; Kamlage et al. 1993). Recently, the presence of a $\mathrm{Na}^{+}$-active electron transport phosphorylation with $\mathrm{Na}^{+}$-Rnf and $\mathrm{Na}^{+}$-ATP synthase was described in C. aceticum, cytochromes are present in addition but of unknown function (Wiechmann and Müller 2021) Important for the context here is the notice that the strains that are currently used in industrial applications do not have cytochromes or quinones.

Now it is time to wake up the cytochromes from sleep. Genetic techniques have been developed for some acetogens, including the cytochrome-containing acetogen M. thermoacetica; for other model organisms such as $S$. ovata, a genetic system is missing. These genetic systems need to be established, to prove or disprove the postulated electron transport chains. In addition, classical biochemical techniques such as the preparation of intact inverted membrane vesicles need to be established for these species. Anyway, the time is ripe to address the role of cytochromes and quinones in acetogens, nearly 50 years after their discovery. The beauty of microbial diversity will certainly increase and with this the fascinating diversity of microbial physiology.

Acknowledgements We are indebted to the Deutsche Forschungsgemeinschaft for continuous support. Furthermore, we are grateful to Dennis Litty for his help in collecting the data for Table 1.

Author contributions The idea for writing the review and concept: FPR and VM; literature search, analysis and study: FPR and VM; Drafting of review: FPR and VM; Editing: FPR and VM. 
Funding Open Access funding enabled and organized by Projekt DEAL.

\section{Declarations}

Conflict of interest The authors declare that there is no conflict of interest.

Open Access This article is licensed under a Creative Commons Attribution 4.0 International License, which permits use, sharing, adaptation, distribution and reproduction in any medium or format, as long as you give appropriate credit to the original author(s) and the source, provide a link to the Creative Commons licence, and indicate if changes were made. The images or other third party material in this article are included in the article's Creative Commons licence, unless indicated otherwise in a credit line to the material. If material is not included in the article's Creative Commons licence and your intended use is not permitted by statutory regulation or exceeds the permitted use, you will need to obtain permission directly from the copyright holder. To view a copy of this licence, visit http://creativecommons.org/licenses/by/4.0/.

\section{References}

Arendsen AF, Soliman MQ, Ragsdale SW (1999) Nitrate-dependent regulation of acetate biosynthesis and nitrate respiration by Clostridium thermoaceticum. J Bacteriol 181:1489-1495

Bache R, Pfennig N (1981) Selective isolation of Acetobacterium woodii on methoxylated aromatic acids and determination of growth yields. Arch Microbiol 130:255-261

Beaty PS, Ljungdahl LG (1990) Thiosulfate reduction by Clostridium thermoaceticum and Clostridium thermoautotrophicum during growth on methanol. Ann Meet Am Soc Microbiol Abstr 1-7:199

Bertsch J, Öppinger C, Hess V, Langer JD, Müller V (2015) Heterotrimeric NADH-oxidizing methylenetetrahydrofolate reductase from the acetogenic bacterium Acetobacterium woodii. J Bacteriol 197:1681-1689

Bertsch J, Siemund AL, Kremp F, Müller V (2016) A novel route for ethanol oxidation in the acetogenic bacterium Acetobacterium woodii: The acetaldehyde/ethanol dehydrogenase pathway. Environ Microbiol 18:2913-2922

Biegel E, Müller V (2010) Bacterial $\mathrm{Na}^{+}$-translocating ferredoxin:NAD ${ }^{+}$oxidoreductase. Proc Natl Acad Sci USA 107:18138-18142

Biegel E, Schmidt S, González JM, Müller V (2011) Biochemistry, evolution and physiological function of the Rnf complex, a novel ion-motive electron transport complex in prokaryotes. Cell Mol Life Sci 68:613-634

Blamey JM, Adams MW (1993) Purification and characterization of pyruvate ferredoxin oxidoreductase from the hyperthermophilic archaeon Pyrococcus furiosus. Biochim Biophys Acta 1161:19-27

Clark JE, Ljungdahl LG (1982) Purification and properties of 5,10-methenyltetrahydrofolate cyclohydrolase from Clostridium formicoaceticum. J Biol Chem 257:3833-3836

Conrad R, Schink B, Phelps TJ (1986) Thermodynamics of $\mathrm{H}_{2}$-consuming and $\mathrm{H}_{2}$-producing metabolic reactions in diverse methanogenic environments under in situ conditions. FEMS Microbiol Ecol 38:353-360

Daniel SL, Wu ZG, Drake HL (1988) Growth of thermophilic acetogenic bacteria on methoxylated aromatic acids. FEMS Microbiol Lett 52:25-28
Das A, Ljungdahl LG (1997) Composition and primary structure of the $\mathrm{F}_{1} \mathrm{~F}_{0}$ ATP synthase from the obligately anaerobic bacterium Clostridium thermoaceticum. J Bacteriol 179:3746-3755

Das A, Hugenholtz J, van Halbeek H, Ljungdahl LG (1989) Structure and function of a menaquinone involved in electron transport in membranes of Clostridium thermoautotrophicum and Clostridium thermoaceticum. J Bacteriol 171:5823-5829

Deppenmeier U, Müller V (2008) Life close to the thermodynamic limit: how methanogenic archaea conserve energy. Results Probl Cell Differ 45:123-152

Deppenmeier U, Müller V, Gottschalk G (1996) Pathways of energy conservation in methanogenic archaea. Arch Microbiol 165:149-163

Diekert G, Ritter M (1982) Nickel requirement of Acetobacterium woodii. J Bacteriol 151:1043-1045

Dobrindt U, Blaut M (1996) Purification and characterization of a membrane-bound hydrogenase from Sporomusa sphaeroides involved in energy-transducing electron transport. Arch Microbiol 165:141-147

Dorn M, Andreesen JR, Gottschalk G (1978) Fumarate reductase of Clostridium formicoaceticum. A peripheral membrane protein. Arch Microbiol 119:7-11

Drake HL, Hu SI, Wood HG (1980) Purification of carbon monoxide dehydrogenase, a nickel enzyme from Clostridium thermocaceticum. J Biol Chem 255:7174-7180

Drake HL, Gößner AS, Daniel SL (2008) Old acetogens, new light. Ann N Y Acad Sci 1125:100-128

Emerson DF, Woolston BM, Liu N, Donnelly M, Currie DH, Stephanopoulos G (2019) Enhancing hydrogen-dependent growth of and carbon dioxide fixation by Clostridium ljungdahlii through nitrate supplementation. Biotechnol Bioeng 116:294-306

Fröstl JM, Seifritz C, Drake HL (1996) Effect of nitrate on the autotrophic metabolism of the acetogens Clostridium thermoautotrophicum and Clostridium thermoaceticum. J Bacteriol 178:4597-4603

Gottschalk G, Thauer RK (2001) The $\mathrm{Na}^{+}$-translocating methyltransferase complex from methanogenic archaea. Biochim Biophys Acta 1505:28-36

Gottwald M, Andreesen JR, LeGall J, Ljungdahl LG (1975) Presence of cytochrome and menaquinone in Clostridium formicoaceticum and Clostridium thermoaceticum. J Bacteriol 122:325-328

Grüber G, Manimekalai MS, Mayer F, Müller V (2014) ATP synthases from archaea: the beauty of a molecular motor. Biochim Biophys Acta 1837:940-952

Hackmann TJ, Firkins JL (2015) Electron transport phosphorylation in rumen butyrivibrios: unprecedented ATP yield for glucose fermentation to butyrate. Front Microbiol 6:622

Hattori S, Kamagata Y, Hanada S, Shoun H (2000) Thermacetogenium phaeum gen. nov., sp. nov., a strictly anaerobic, thermophilic, syntrophic acetate-oxidizing bacterium. Int J Syst Evol Microbiol 50:1601-1609

Hess V, Schuchmann K, Müller V (2013) The ferredoxin:NAD ${ }^{+}$oxidoreductase (Rnf) from the acetogen Acetobacterium woodii requires $\mathrm{Na}^{+}$and is reversibly coupled to the membrane potential. J Biol Chem 288:31496-31502

Hess V, Gallegos R, Jones JA, Barquera B, Malamy MH, Müller V (2016) Occurrence of ferredoxin:NAD ${ }^{+}$oxidoreductase activity and its ion specificity in several Gram-positive and Gram-negative bacteria. Peer J 4:e1515

Himes RH, Harmony JA (1973) Formyltetrahydrofolate synthetase. CRC Crit Rev Biochem 1:501-535

Homma M, Kutsukake K, Iino T (1985) Structural genes for flagellar hook-associated proteins in Salmonella typhimurium. J Bacteriol 163:464-471

Hu SI, Drake HL, Wood HG (1982) Synthesis of acetyl coenzyme A from carbon monoxide, methyltetrahydrofolate, and coenzyme 
A by enzymes from Clostridium thermoaceticum. J Bacteriol 149:440-448

Hugenholtz J, Ljungdahl LG (1989) Electron transport and electrochemical proton gradient in membrane vesicles of Clostridium thermoaceticum. J Bacteriol 171:2873-2875

Hugenholtz J, Ljungdahl LG (1990) Metabolism and energy generation in homoacetogenic clostridia. FEMS Microbiol Rev 87:383-389

Hugenholtz J, Ivey DM, Ljungdahl LG (1987) Carbon monoxidedriven electron transport in Clostridium thermoautotrophicum membranes. J Bacteriol 169:5845-5847

Imkamp F, Biegel E, Jayamani E, Buckel W, Müller V (2007) Dissection of the caffeate respiratory chain in the acetogen Acetobacterium woodii: Indications for a Rnf-type NADH dehydrogenase as coupling site. J Bacteriol 189:8145-8153

Kamlage B, Blaut M (1993) Isolation of a cytochrome-deficient mutant strain of Sporomusa sphaeroides not capable of oxidizing methyl groups. J Bacteriol 175:3043-3050

Kamlage B, Boelter A, Blaut M (1993) Spectroscopic and potentiometric characterization of cytochromes in 2 Sporomusa species and their expression during growth on selected substrates. Arch Microbiol 159:189-196

Kaster AK, Moll J, Parey K, Thauer RK (2011) Coupling of ferredoxin and heterodisulfide reduction via electron bifurcation in hydrogenotrophic methanogenic archaea. Proc Natl Acad Sci USA 108:2981-2986

Kawagishi I, Imagawa M, Imae Y, Mccarter L, Homma M (1996) The sodium-driven polar flagellar motor of marine Vibrio as the mechanosensor that regulates lateral flagellar expression. Mol Microbiol 20:693-699

Keller A, Schink B, Müller N (2019) Energy-conserving enzyme systems active during syntrophic acetate oxidation in the thermophilic bacterium Thermacetogenium phaeum. Front Microbiol 10:2785

Kengen SW, Mosterd JJ, Nelissen RLH, Keltjens JT, van der Drift C, Vogels GD (1988) Reductive activation of the methyl-tetrahydromethanopterin: coenzyme M methyltransferase from Methanobacterium thermoautotrophicum strain $\Delta \mathrm{H}$. Arch Microbiol 150:405-412

Khafizov K, Perez C, Koshy C, Quick M, Fendler K, Ziegler C, Forrest LR (2012) Investigation of the sodium-binding sites in the sodium-coupled betaine transporter BetP. Proc Natl Acad Sci USA 109:E3035-E3044

Kröger A, Biel S, Simon J, Gross R, Unden G, Lancaster CR (2002) Fumarate respiration of Wolinella succinogenes: enzymology, energetics and coupling mechanism. Biochim Biophys Acta 1553:23-38

Ledbetter RN, Garcia Costas AM, Lubner CE, Mulder DW, Tokmina-Lukaszewska M, Artz JH, Patterson A, Magnuson TS, Jay ZJ, Duan HD, Miller J, Plunkett MH, Hoben JP, Barney BM, Carlson RP, Miller AF, Bothner B, King PW, Peters JW, Seefeldt LC (2017) The electron bifurcating FixABCX protein complex from Azotobacter vinelandii: generation of low-potential reducing equivalents for nitrogenase catalysis. Biochemistry 56:4177-4190

Leigh JA, Rinehart KL, Wolfe RS (1985) Methanofuran (carbon dioxide reducing factor), a formyl carrier in methane production from carbon dioxide in Methanobacterium. Biochemistry 24:995-999

Lie TJ, Costa KC, Lupa B, Korpole S, Whitman WB, Leigh JA (2012) Essential anaplerotic role for the energy-converting hydrogenase Eha in hydrogenotrophic methanogenesis. Proc Natl Acad Sci USA 109:15473-15478

Ljungdahl LG (1986) The autotrophic pathway of acetate synthesis in acetogenic bacteria. Ann Rev Microbiol 40:415-450

Luoto HH, Baykov AA, Lahti R, Malinen AM (2013) Membrane-integral pyrophosphatase subfamily capable of translocating both $\mathrm{Na}^{+}$ and $\mathrm{H}^{+}$. Proc Natl Acad Sci USA 110:1255-1260
Matthies C, Freiberger A, Drake HL (1993) Fumarate dissimilation and differential reductant flow by Clostridium formicoaceticum and Clostridium aceticum. Arch Microbiol 160:273-278

Misoph M, Drake HL (1996) Effect of $\mathrm{CO}_{2}$ on the fermentation capacities of the acetogen Peptostreptococcus productus U-1. J Bacteriol 178:3140-3145

Misoph M, Daniel SL, Drake HL (1996) Bidirectional usage of ferulate by the acetogen Peptostreptococcus productus $\mathrm{U}-1: \mathrm{CO}_{2}$ and aromatic acrylate groups as competing electron acceptors. Microbiology 142:1983-1988

Mock J, Wang S, Huang H, Kahnt J, Thauer RK (2014) Evidence for a hexaheteromeric methylenetetrahydrofolate reductase in Moorella thermoacetica. J Bacteriol 196:3303-3314

Moon T, Dönig J, Kramer S, Poehlein A, Daniel R, Müller V (2021) Formate metabolism in the acetogenic bacterium Acetobacterium woodii. Environ Microbiol 23:4214-4227

Moore MR, O'Brien WE, Ljungdahl LG (1974) Purification and characterization of nicotinamide adenine dinucleotide-dependent methylenetetrahydrofolate dehydrogenase from Clostridium formicoaceticum. J Biol Chem 249:5250-5253

Müller V (2003) Energy conservation in acetogenic bacteria. Appl Environ Microbiol 69:6345-6353

Müller V, Grüber G (2003) ATP synthases: structure, function and evolution of unique energy converters. Cell Mol Life Sci 60:474-494

Müller V, Blaut M, Gottschalk G (1988a) The transmembrane electrochemical gradient of $\mathrm{Na}^{+}$as driving force for methanol oxidation in Methanosarcina barkeri. Eur J Biochem 172:601-606

Müller V, Winner C, Gottschalk G (1988b) Electron transport-driven sodium extrusion during methanogenesis from formaldehyde $+\mathrm{H}_{2}$ by Methanosarcina barkeri. Eur J Biochem 178:519-525

Müller V, Ruppert C, Lemker T (1999) Structure and function of the $\mathrm{A}_{1} \mathrm{~A}_{\mathrm{O}}$ ATPases from methanogenic archaea. J Bioenerg Biomembr $31: 15-28$

Müller V, Frerichs J (2013) Acetogenic bacteria. In: Encyclopedia of life science. John Wiley \& Sons Ltd, Chichester, UK

Öppinger C, Kremp F, Müller V (2021) Is reduced ferredoxin the physiological electron donor for MetVF-type methylenetetrahydrofolate reductases in acetogenesis? Int Microbiol. https://doi.org/10.1007/ s10123-021-00190-0

Pezacka E, Wood HG (1984) The synthesis of acetyl-CoA by Clostridium thermoaceticum from carbon dioxide, hydrogen, coenzyme A and methyltetrahydrofolate. Arch Microbiol 137:63-69

Pierce E, Xie G, Barabote RD, Saunders E, Han CS, Detter JC, Richardson P, Brettin TS, Das A, Ljungdahl LG, Ragsdale SW (2008) The complete genome sequence of Moorella thermoacetica (f. Clostridium thermoaceticum). Environ Microbiol 10:2550-2573

Poehlein A, Cebulla M, Ilg MM, Bengelsdorf FR, Schiel-Bengelsdorf B, Whited G, Andreesen JR, Gottschalk G, Daniel R, Dürre P (2015) The complete genome sequence of Clostridium aceticum: a missing link between Rnf- and cytochrome-containing autotrophic acetogens. Mbio 6:e01168-e1215

Ramos AR, Grein F, Oliveira GP, Venceslau SS, Keller KL, Wall JD, Pereira IAC (2015) The FlxABCD-HdrABC proteins correspond to a novel NADH dehydrogenase/heterodisulfide reductase widespread in anaerobic bacteria and involved in ethanol metabolism in Desulfovibrio vulgaris Hildenborough. Environ Microbiol 17:2288-2305

Raybuck SA, Bastian NR, Orme-Johnson WH, Walsh CT (1988) Kinetic characterization of the carbon monoxide-acetyl-CoA (carbonyl group) exchange activity of the acetyl-CoA synthesizing $\mathrm{CO}$ dehydrogenase from Clostridium thermoaceticum. Biochemistry 27:7698-7702

Reidlinger J, Müller V (1994) Purification of ATP synthase from Acetobacterium woodii and identification as a $\mathrm{Na}^{+}$-translocating $\mathrm{F}_{1} \mathrm{~F}_{\mathrm{O}}$-type enzyme. Eur J Biochem 223:275-283 
Rosenbaum FP, Poehlein A, Egelkamp R, Daniel R, Harder S, Schlüter $\mathrm{H}$, Schoelmerich MC (2021) Lactate metabolism in strictly anaerobic microorganisms with a soluble $\mathrm{NAD}^{+}$-dependent L-lactate dehydrogenase. Environ Microbiol 23:4661-4672

Rouvière P, Wolfe RS (1988) Novel biochemistry of methanogenesis. J Biol Chem 263:7913-7916

Schink B (1994) Diversity, ecology, and isolation of acetogenic bacteria. In: Drake HL (ed) Acetogenesis. Chapman \& Hall, New York, pp 197-235

Schoelmerich MC, Müller V (2019) Energy conservation by a hydrogenase-dependent chemiosmotic mechanism in an ancient metabolic pathway. Proc Natl Acad Sci USA 116:6329-6334

Schoelmerich MC, Müller V (2020) Energy-converting hydrogenases: the link between $\mathrm{H}_{2}$ metabolism and energy conservation. Cell Mol Life Sci 77:1461-1481

Schoelmerich MC, Katsyv A, Dönig J, Hackmann TJ, Müller V (2020) Energy conservation involving 2 respiratory circuits. Proc Natl Acad Sci USA 117:1167-1173

Schuchmann K, Müller V (2012) A bacterial electron bifurcating hydrogenase. J Biol Chem 287:31165-31171

Schuchmann K, Müller V (2014) Autotrophy at the thermodynamic limit of life: a model for energy conservation in acetogenic bacteria. Nat Rev Microbiol 12:809-821

Schuchmann K, Müller V (2016) Energetics and application of heterotrophy in acetogenic bacteria. Appl Environ Microbiol 82:4056-4069

Seifritz C, Daniel SL, Gößner A, Drake HL (1993) Nitrate as a preferred electron sink for the acetogen Clostridium thermoaceticum. J Bacteriol 175:8008-8013

Seifritz C, Fröstl JM, Drake HL, Daniel SL (2002) Influence of nitrate on oxalate- and glyoxylate-dependent growth and acetogenesis by Moorella thermoacetica. Arch Microbiol 178:457-464

Seifritz C, Drake HL, Daniel SL (2003) Nitrite as an energy-conserving electron sink for the acetogenic bacterium Moorella thermoacetica. Curr Microbiol 46:329-333

Streif S, Staudinger WF, Marwan W, Oesterhelt D (2008) Flagellar rotation in the archaeon Halobacterium salinarum depends on ATP. J Mol Biol 384:1-8

Thauer RK, Jungermann K, Decker K (1977) Energy conservation in chemotrophic anaerobic bacteria. Bact Rev 41:100-180

Thauer RK, Kaster AK, Seedorf H, Buckel W, Hedderich R (2008) Methanogenic archaea: ecologically relevant differences in energy conservation. Nat Rev Microbiol 6:579-591

Thauer RK, Kaster AK, Goenrich M, Schick M, Hiromoto T, Shima S (2010) Hydrogenases from methanogenic archaea, nickel, a novel cofactor, and $\mathrm{H}_{2}$ storage. Annu Rev Biochem 79:507-536
Tremblay PL, Zhang T, Dar SA, Leang C, Lovley DR (2012) The Rnf complex of Clostridium ljungdahlii is a proton-translocating ferredoxin:NAD ${ }^{+}$oxidoreductase essential for autotrophic growth. Mbio 4:e00406-e412

Tschech A, Pfennig N (1984) Growth yield increase linked to caffeate reduction in Acetobacterium woodii. Arch Microbiol 137:163-167

van Beelen P, Labro JF, Keltjens JT, Geerts WJ, Vogels GD, Laarhoven WH, Guijt W, Haasnoot CA (1984) Derivatives of methanopterin, a coenzyme involved in methanogenesis. Eur J Biochem 139:359-365

Visser M, Pieterse MM, Pinkse MW, Nijsse B, Verhaert PD, de Vos WM, Schaap PJ, Stams AJ (2016) Unravelling the one-carbon metabolism of the acetogen Sporomusa strain An 4 by genome and proteome analysis. Environ Microbiol 18:2843-2855

Wagner T, Koch J, Ermler U, Shima S (2017) Methanogenic heterodisulfide reductase (HdrABC-MvhAGD) uses two noncubane [4Fe4S] clusters for reduction. Science 357:699-703

Weghoff MC, Bertsch J, Müller V (2015) A novel mode of lactate metabolism in strictly anaerobic bacteria. Environ Microbiol 17:670-677

Welte C, Deppenmeier U (2014) Bioenergetics and anaerobic respiratory chains of aceticlastic methanogens. Biochim Biophys Acta 1837:1130-1147

Welte C, Krätzer C, Deppenmeier U (2010) Involvement of Ech hydrogenase in energy conservation of Methanosarcina mazei. FEBS J 277:3396-3403

Westphal L, Wiechmann A, Baker J, Minton NP, Müller V (2018) The Rnf complex is an energy coupled transhydrogenase essential to reversibly link cellular NADH and ferredoxin pools in the acetogen Acetobacterium woodii. J Bacteriol 200:e00357-e1318

Wiechmann A, Müller V (2021) Energy conservation in the acetogenic bacterium Clostridium aceticum. Microorganisms 9:258

Wohlfarth G, Diekert G (1991) Thermodynamics of methylenetetrahydrofolate reduction to methyltetrahydrofolate and its implications for the energy metabolism of homoacetogenic bacteria. Arch Microbiol 155:378-381

Wood HG, Ragsdale SW, Pezacka E (1986) The acetyl-CoA pathway: a newly discovered pathway of autotrophic growth. Trends Biochem Sci 11:14-18

Publisher's Note Springer Nature remains neutral with regard to jurisdictional claims in published maps and institutional affiliations. 